Belajar Nilai Hidup dari Manusia Pakis

Dr. Putu Sabda Jayendra, S.Pd.H., M.Pd.H.

Ida Bagus Arya Lawa Manuaba, M.Pd.

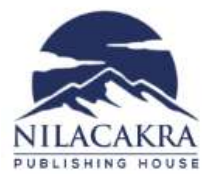

2020 


\section{Mongah: Belajar Nilai Hidup dari Manusia Pakis}

Dr. Putu Sabda Jayendra, S.Pd.H., M.Pd.H.

Ida Bagus Arya Lawa Manuaba, M.Pd.

Kategori: budaya \& filsafat

Desain cover \& tata letak isi | Yudha Pradhana

Versi digital | Nindy Widiastuti

A5 $(14,8 \times 21 \mathrm{~cm})$

Cetakan Pertama: Desember 2020

Tersedia di Google Play Books mulai Desember 2020

\section{ISBN}

P 978-623-6748-55-8

E 978-623-6748-56-5

Hak cipta (c)2020 pada penulis

Hak cipta desain cover pada penerbit

Dilarang menerjemahkan, memfotokopi, atau memperbanyak sebagian atau seluruh isi buku ini tanpa izin tertulis dari penerbit.

Diterbitkan oleh

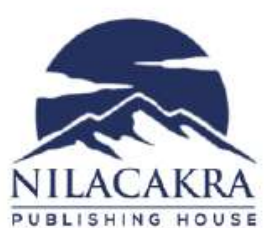

\section{NILACAKRA ${ }^{\mathrm{TM}}$}

Anggota IKAPI (no. 023/BAI/2019)

Jl. Raya Darmasaba-Lukluk,

Badung, Bali 80352. Telp: (0361) 424612

Website: www.penerbitbali.com;

E-mail: nilacakrapublisher@gmail.com

Instagram: @penerbit_nilacakra 


\section{KATA

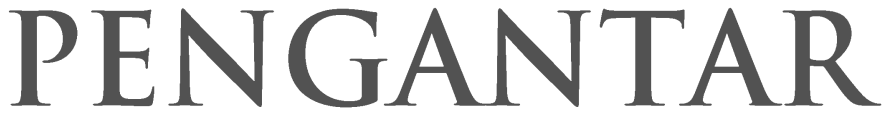

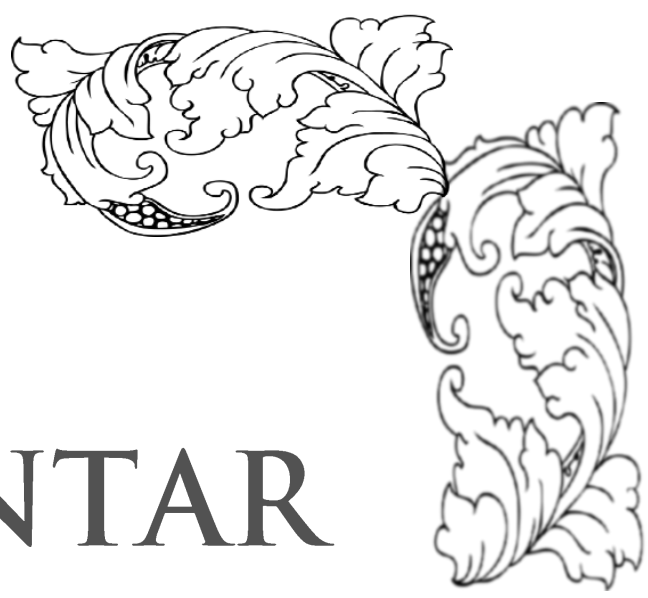

asa angayubagia kami selaku tim penulis haturkan ke-
hadapan Ida Sang Hyang Widhi Wasa, karena akhirnya
penulisan buku ini dapat terselesaikan. Lewat buku ini, kami mencoba untuk mengeksplorasi sekaligus mengulas eksistensi dari tarian sakral Mongah, yang hanya terdapat satu-satunya di Desa Bunutin, Kecamatan Kintamani, Kabupaten Bangli. Tarian sakral Mongah ini sangat menarik untuk dieksplorasi karena menampilkan corak yang kuno, dengan ciri khas tanaman pakis sebagai pakaian atau kostumnya. Selain itu, filosofinya yang sangat kental dan mendalam rupanya sangat berkaitan erat dengan eksistensi masyarakat Desa Bunutin, sehingga hal ini tentu saja menjadikannya tidak hanya sekadar tarian yang bersifat ritual, namun juga sebuah mutiara budaya yang sangat berharga.

Awal perkenalan kami dengan sosok 'manusia pakis' ini berawal di awal tahun 2019. Pada waktu itu, rekan kami, Dr. Sabda, baru saja menyelesaikan buku "Barong Brutuk"-nya yang membahas tentang eksistensi kebudayaan pra-Hindu di Terunyan. Buku itu rupanya menjadi buku komprehensif mengenai seluk-beluk tarian sakral Terunyan ini, setelah James Danandjaja mengulasnya lebih dari dua dasawarsa 
lalu. Barong Brutuk ini bahkan dijadikan sebuah cerpen oleh Saudara Ida Bagus Arya, yang mendapat penghargaan di Festival Bali Jani 2019 lalu.

Kemudian, kami menemukan satu-dua jejak samar mengenai eksistensi tarian sejenis yang ada di Desa Bunutin, Kintamani. Sayang sekali, artikel ilmiah yang kami temukan di antara tumpukan judul penelitian di Google Scholar itu kurang mengungkapkan asal mula, etimologi dan dasardasar filsafat pertunjukan tarian Mongah ini.

Akhirnya kami menelusuri jejak yang samar itu hingga tersasar ke perbukitan Kintamani yang penuh ladang jeruk dan bawang, menyusuri Desa Bayung Gede yang klasik, melewati jembatan sungai yang putus, dan akhirnya tiba di Desa Bunutin yang elok, tempat asal sang Mongah ini.

Dalam penulisan buku ini, kami mengandalkan observasi langsung ke lokasi pementasan tarian sakral ini, dan informasi-informasi berharga dari para informan setempat, serta sedikit sumber-sumber kepustakaan sebagai penunjang. Tidak dapat dipungkiri, bahwa dalam proses riset yang kami lakukan, kesulitan terbesar adalah menemukan catatan atau manuskrip-manuskrip yang mengulas eksistensi Tari Mongah secara spesifik. Publikasipublikasi ilmiah yang mengungkap keberadaan tarian ini pun amat sangat terbatas, sehingga informasi dari para informan setempat menjadi sangat penting sebagai acuan dasar dalam menuliskan buku ini. Tentu saja setelah melakukan komparasi dari informan satu ke informan lainnya. Perbedaan versi penyampaian sudah pasti ada, namun rupanya tidak terlalu signifikan, sehingga data yang disampaikan secara lisan dapat dipertanggungjawabkan 
kebenarannya. Namun demikian kami memohon maaf yang sebesar-besarnya atas segala keterbatasan yang ada dalam penulisan buku ini. Masukan-masukan dari berbagai pihak tentu saja sangat diharapkan demi penyempurnaan di kemudian hari, disertai dengan harapan akan ada peneliti dan penulis lainnya yang akan lanjut untuk mengeksplorasi lebih mendalam lagi terkait eksistensi tarian Mongah ini.

Pada kesempatan ini kami menyampaikan rasa terima kasih dan penghormatan setinggi-tingginya kepada seluruh perangkat desa dan prajuru adat Desa Bunutin atas bantuan dan informasi-informasi berharga yang diberikan. Ucapan terima kasih yang mendalam secara khusus juga kami sampaikan pada bapak Jro Bau Kasih, yang sangat intens berkomunikasi dengan kami selama penulisan buku ini, bahkan dengan sabar menjawab pertanyaan-pertanyaan kami melalui media telepon dan Whatsapp. Begitu pula dengan Kelihan Sekaa Teruna, I Wayan Sumerta, S.Pd., yang sekaligus sebagai guru di SD Negeri Bunutin. Peranannya sangat besar dalam mengantarkan perjalanan kami mencari informan-informan handal untuk menggali berbagai informasi yang berharga, serta intens pula berkomunikasi dengan kami melalui Whatsapp. Akhirnya ucapan terima kasih yang tak terhingga kami sampaikan kepada seluruh masyarakat Desa Bunutin, Kintamani, Bangli atas segala keramah-tamahan dan bantuan yang diberikan. Semoga Ida Sang Hyang Widhi Wasa senantiasa melindungi dan memberikan kerahayuan untuk seluruh masyarakat Desa Bunutin, Kintamani.

Denpasar, 11 Oktober 2020 Tim Penulis. 


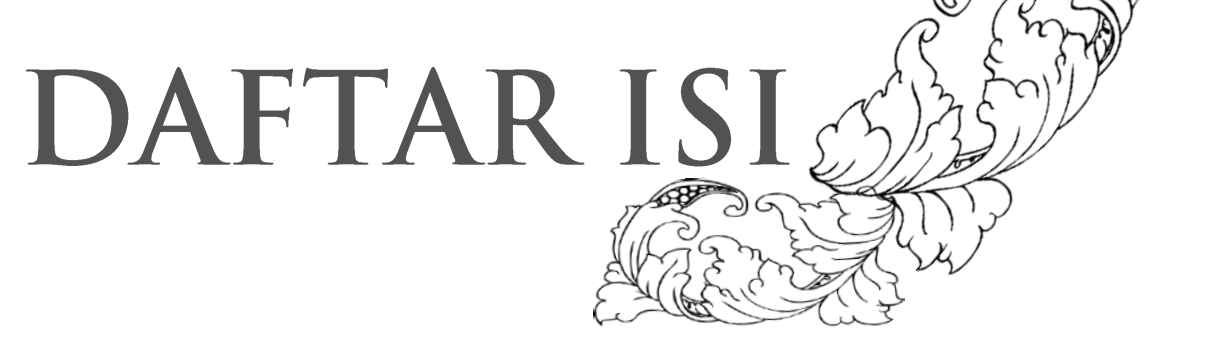

Kata Pengantar vi

Daftar Isi ix

Bab I Desa Bunutin: Sebuah Pengantar 1

Bab II Konsep dan Keunikan Tarian Mongah 7

A. Komposisi Pakaian dari Tanaman-Tanaman Liar 24

B. Merupakan Refleksi dari Histori Desa Bunutan 32

C. Merepresentasikan Kekuatan Alam Semesta 38

D. Tidak Memiliki Pakem Tarian Baku 42

E. Penarinya Merupakan Para Pemuda yang Belum Menikah

Bab III Proses Pementasan Tari Mongah 51

A. Seleksi dan Pembagian Tugas Para Teruna 57

B. Mencari Pakis dan Kelengkapan Kostum Lainnya 60

C. Pembuatan Mongah 61

D. Tahap Pementasan 63

E. Pralina Mongah dan Tahap Akhir 79 
Bab IV Belajar Keharmonisan Hidup dari Para Mongah 83
A. Kesusilaan
85
B. Hidup Selaras dengan Alam
94

Daftar Pustaka

101 


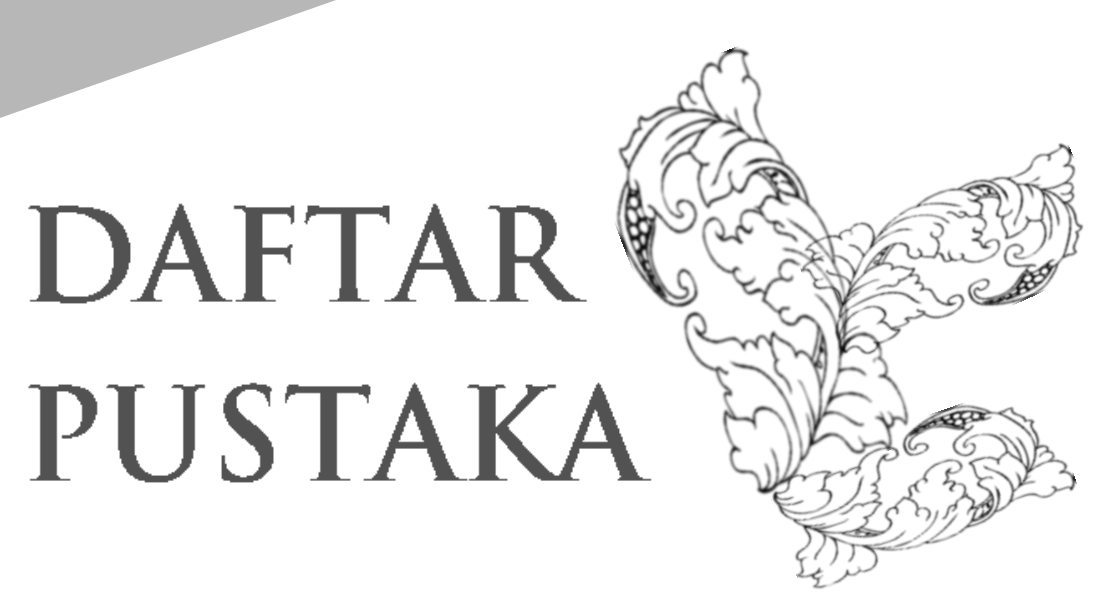

Anggraini, D., \& Hasnawati, H. (2016). Perkembangan Seni Tari: Pendidikan dan Masyarakat. Jurnal PGSD: Jurnal Ilmiah Pendidikan Guru Sekolah Dasar, 9(3), 287-293.

Bagus, A. A. (2015). Arca Ganesa Bertangan Delapan Belas di Pura Pingit Melamba Bunutin, Kintamani, Bangli. Jurnal Forum Arkeologi (Vol. 28, No. 1, pp. 25-34).

http://balaiarkeologibali.kemdikbud.go.id/informasi/berita/bentang -budaya-kosmologis-kerajaan-bali-kuno-kajian-kearifanlingkungan-dalam-upaya-mendukung-pembangunanberkelanjutan (diakses Oktober 2020).

https://warisanbudaya.kemdikbud.go.id/?newdetail\&detailCatat= 3137 (diakses Oktober 2020).

Iryanto, V. E. (2000). Tari Bali: Sebuah Telaah Historis (Bali Dance: a Historical Reasearch). Harmonia: Journal of Arts Research and Education, 1(2). 
Jayendra, Putu Sabda. 2016. Pendidikan Agama Hindu Untuk Perguruan Tinggi. Denpasar: Vidia.

Jayendra, Putu Sabda. 2019. Barong Brutuk, Penjaga Jiwa dari Tanah Bali Kuno. Badung: Nilacakra.

Kadjeng, I Nyoman, dkk. 2007. Sarasamuccaya. Denpasar: Pemerintah Provinsi Bali.

Koentjaraningrat. 2004. Manusia dan Kebudayaan di Indonesia. Jakarta: Djambatan.

Koentjaraningrat. 2009. Pengantar Ilmu Antropologi. Jakarta: Rineka Cipta.

Mantra, I. B. 2007. Bhagawadgita. Denpasar: Pemerintah Provinsi Bali.

Narisma, N. K. A., Suka, \& I. G., Sama. (2018). Pementasan Tari Mongah dalam Upacara Pangwangan di Desa Bunutin, Kecamatan Kintamani, Bangli. Jurnal Humanis 22(1), 66-74

Pals, Daniel L. 2001. Seven Theories of Religion. Yogyakarta: Qalam.

Parmajaya, I Putu Gede dan I Made Ariasa Giri. 2007. Seni Sakral. Denpasar: Fakultas Dharma Acarya Institut Hindu Dharma Negeri Denpasar. 
Sardiana, I. K., \& Dinata, K. K. (2010). Studi pemanfaatan tanaman pada kegiatan ritual (upakara) oleh umat Hindu di Bali. Jurnal Bumi Lestari, 10(1), 123-127.

Surada, I Made. (2013). Ideologi Kedok Muka Kala Pada Bangunan Suci Di Bali Telaah Tentang Ideologi-Religi. Jurnal Forum Arkeologi (Vol. 26, No. 1, pp. 52-62).

Wicaksana, I Dewa Ketut, 2007. Wayang Sapu Leger, Fungsi dan Maknanya dalam Masyarakat Bali. Denpasar : Pustaka Bali Post.

Yulianti, Ni Ketut Dewi dkk. 2014. “Eksistensi Tari Bali dan Jawa dalam Bahasa Indonesia dan Inggris", dalam Jurnal Segara Widya, Vol. 2, No.1. 